\title{
Food and beverage advertising on children's TV channels in Argentina: Frequency, duration, and nutritional quality
}

\author{
Alicia Rovirosa, Biochemist ${ }^{a}$, María Elisa Zapata, B.S. and Master of Science ${ }^{b}$, \\ Paula Gómez, B.S. ${ }^{c}$, Susana Gotthelf, M.D. ${ }^{d}$ and Daniel Ferrante, M.D. ${ }^{e}$
}

\begin{abstract}
Food and beverage marketing has beenidentified as one of the determinants of unhealthy food and beverage consumption in the child population. Objective. To determine the frequency and duration of food and beverage advertising in children's programming and the nutritional quality of advertised food and beverages.

Methods. Descriptive, cross-sectional study. Children's cable and broadcast channel programming was recorded in two periods: over the week and on the weekend. The type, quantity, and duration of commercials were recorded. The nutritional quality of advertised food and beverages was analyzed.
\end{abstract}

a. Child Nutrition Study Center.

b. School of Chemistry, Universidad de Centro Educativo Latinoamericano, Rosario, Santa Fe.

c. School of Exact Sciences, Universidad de Belgrano.

d. National Center for Nutrition Research.

e. Ministry of Health of the Autonomous City of Buenos Aires.

E-mail address:

María E. Zapata, B.S. and Master of Science: mariaelisazapata@ gmail.com

\section{Funding:}

This research study was conducted with the support of the Ramón CarrilloArturo Oñativia scholarship program, for a multicenter study, granted by the National Ministry of Health of Argentina through the National Health Research Committee.

Conflict of interest: None.

Received: 4-20-2016 Accepted: 9-22-2016
Results. A total of 402.3 hours of children's programming were recorded. In total, 3711 commercials were identified. Among these, $20.9 \%$ corresponded to food and beverages, i.e., an average of $1.9 \pm 1.0$ commercials per hour or equivalent to $0.68 \pm 0.36 \mathrm{~min} /$ hour. Dairy products, candies, and fast-food meals were the most advertised food products. Only a third of advertised food and beverages (35.8\%) were categorized as healthy as per the nutrient profiling system. Based on the traffic light labeling system, $50 \%$ of advertised food and beverages were high in sugar, $25 \%$ were high in saturated fat, and approximately $15 \%$ were high in sodium or fat.

Conclusion. Food and beverage advertising accounted for $20 \%$ of television advertising time. The most advertised products were dairy products, followed by candies and sweet snacks, fast-food meals, and beverages. Two-thirds of advertised food and beverages were considered unhealthy.

Key words: television, food publicity, beverages, child, food quality.

http:/ /dx.doi.org/10.5546/aap.2017.eng.28

\section{INTRODUCTION}

The prevalence of overweight and obesity among children and adolescents has increased in Argentina over the past decades. ${ }^{1}$ This phenomenon is not different from what is occurring in other countries in the same region and worldwide, and it may have an impact on the development of chronic diseases in the mid-run, especially among the most disadvantaged populations. ${ }^{2}$ In this setting, an unhealthy diet is a risk factor for a future chronic condition, which starts during childhood and increases over life. ${ }^{3}$

One of the determinants of food consumption that is high in calories, saturated fat, sodium, and sugar is the marketing of food aimed at the child population.

Data from systematic reviews on the size, nature, and effects of food promotion to children have concluded that this type of strategy is a worldwide phenomenon that tends to be pluralistic and integrated, in addition to using countless channels and messages to get across. ${ }^{4}$

Studies have also demonstrated that television advertising influences on children's food preferences, purchase requests, and consumption guidelines, ${ }^{5,8}$ and that children are more aware of the brands that have the greatest advertising pressure, and prefer products whose campaigns are tied to some sort of marketing action. ${ }^{4}$ Although television is still a relevant media, it has progressively been complemented by an increasingly multifaceted combination of advertising messages focused on identifying a brand and establishing consumer relations. ${ }^{4}$

In different settings, this had led to the publication of recommendations for countries to implement adequate regulatory mechanisms for the promotion of food and non-alcoholic beverages targeted at children., ${ }^{4,-11}$

To date, no publications have been made that document the exposure to food and beverage advertising 
in Argentina and its power. The objective of this study was to determine the frequency and duration of food and beverage advertising in children's cable and broadcast channel programming and the nutritional quality of advertised food and beverages.

\section{MATERIALS AND METHODS}

This was a descriptive, cross-sectional study. Children's cable TV channels and children's programming in broadcast TV channels aired in the Autonomous City of Buenos Aires were monitored during weekdays and on weekends; $88.9 \%$ of the city's population has paid cable television. ${ }^{12}$ All children's cable channels available in the Autonomous City of Buenos Aires were included: Boomerang ${ }^{\circledR}$, Cartoon Network $^{\circledR}$, Disney Channel ${ }^{\circledR}$, Disney Junior ${ }^{\circledR}$, Disney $\mathrm{XD}^{\circledR}$, Nickelodeon ${ }^{\circledR}$, and Paka-Paka ${ }^{\circledR}$, together with broadcast television children's shows (channels 9 and 13, TV Pública, América, and Telefé). Shows were recorded using an electronic recording device (Encore Electronics ${ }^{\circledR}$ ), model ENUTV-4.

Investigators recorded shows in two periods, between August and November of 2013 and between January and April of 2014, on a weekday and on a weekend day selected at random, between 6 am and 10 pm for cable TV channels, and at the time corresponding to children's shows in the case of broadcast TV channels.

Advertisement was defined as the message targeted at making a product, event, or similar goods known to the public.

For the purpose of this investigation, commercials were analyzed, particularly those corresponding to food and beverages shown during children's television shows. The duration (minutes and seconds) of the following was recorded: television show, commercials corresponding to the channel's programming, food and beverage commercials, toy commercials, and other commercials outside these categories. Results were described as total time destined to advertising (minutes/hour), total time destined to food and beverage advertising, total time destined to other types of commercials (toys, channel's programming, other), and number of food and beverage commercials per hour.

Advertised food and beverages were grouped into eight categories based on their nutritional characteristics, and each category was analyzed in terms of frequency and duration.

The nutritional quality of advertised food and beverages was assessed using two nutritional profile models developed by the United Kingdom Food Standards Agency (FSA). The Nutrient Profiling model, ${ }^{13}$ developed for the purpose of regulating food and beverage advertising targeted at children, considers nutrient content per $100 \mathrm{~g}$; a score is assigned based on the nutrients to limit (sugar, saturated fat, sodium, and calories [score A]) and on the fruit, vegetable, tree nut, fiber, and protein content (score $\mathrm{C}$ ). A total score is obtained based on the difference; healthy food products are those with a score below 4 , and healthy beverages are those with a score below 1 . Any food or beverage that did not meet these criteria was considered unhealthy. The traffic light labeling system, ${ }^{14}$ also developed by the FSA to label the front of food packs, assesses total fat, saturated fat, total sugar, and sodium content per $100 \mathrm{~g}$ of food and per serving size, and classifies such content into three levels: high, medium, or low. Food composition data were obtained from food labels or from the manufacturer's website and, in the case of sugar content (which is not mandatory and is, therefore, available for some products only), data about similar products from other companies or food composition tables were used to supplement the nutrition facts information.

A descriptive statistical analysis was performed; results were reported as average, standard deviation, range, and percentage.

\section{Ethical considerations}

All aspects related to the development of this project have been conducted in accordance with valid national and international standards.

\section{RESULTS}

A total of 422 hours of programming were recorded. Out of these, 3.7 hours were unacceptable due to a recording interruption, and 16 hours were excluded because they corresponded to Paka-Paka, a broadcast channel that does not air commercials. Finally, 402.3 hours of children's programming were analyzed; 356.5 hours corresponded to children's cable channels, and 45.8 hours were from children's shows aired on broadcast channels. Advertising accounted for $7.3 \%$ of all monitored time; $4.2 \%$ corresponded to various products; $1.9 \%$, to toys, and $1.2 \%$, to food and beverages.

Over the studied period, 3711 commercials were recorded; approximately $20 \%$ of these corresponded to food and beverages, 33\% were for toys, and most were for some other type of product (Table 1). Food and beverage commercials 
accounted for less than 1 minute per hour in average whereas almost 2 food and beverage commercials were shown per hour, which is close to the number of toy commercials (Table 1).

The most advertised products were dairy products, which accounted for almost a third of all food and beverage commercials, followed by candies and sweet snacks (14\%), fast-food meals $(12 \%)$, and beverages $(12 \%)$.
Based on the most commonly advertised type of food, it was evident that dairy desserts, fastfood meals, yogurt, and modified milk for 1 to 3-year-olds were the products with the highest number of commercials (Figure 1).

Based on the advertised food and beverage nutrient composition according to the nutrient profiling system, it was observed that a third $(n=276,35.8 \%)$ fitted into the healthy food

TABLE 1. Frequency and duration of commercials broadcast in children's programming by type of product

\begin{tabular}{lcccc}
\hline Type of advertising & Commercials $(\mathbf{n})$ & $\%$ & Duration $_{(\mathbf{m i n} / \mathbf{h})^{\mathbf{a}}}$ & ${\text { Number of commercials per } \mathbf{h}^{\mathbf{a}}}$ \\
\hline Food and beverages & 774 & 20.9 & $0.68 \pm 0.36(0-1.42)$ & $1.9 \pm 1.0(0-3.57)$ \\
Toys & 1114 & 30.0 & $0.69 \pm 1.16(0-4.27)$ & $1.7 \pm 2.8(0-13.7)$ \\
Other & 1823 & 49.1 & $1.74 \pm 2.82(0.25-13.65)$ & $7.3 \pm 6.0(0.8-24.0)$ \\
Total & 3711 & $\mathbf{1 0 0}$ & $\mathbf{4 . 9} \pm \mathbf{2 . 2 ( 1 . 2 - 8 . 8 )}$ & $\mathbf{1 1 . 0} \pm \mathbf{6 . 0}(\mathbf{2 . 6 - 2 6 . 0 )}$ \\
\hline
\end{tabular}

a Values corresponding to mean \pm standard deviation, range.

FIGURE 1. Number of commercials by type of food and beverage

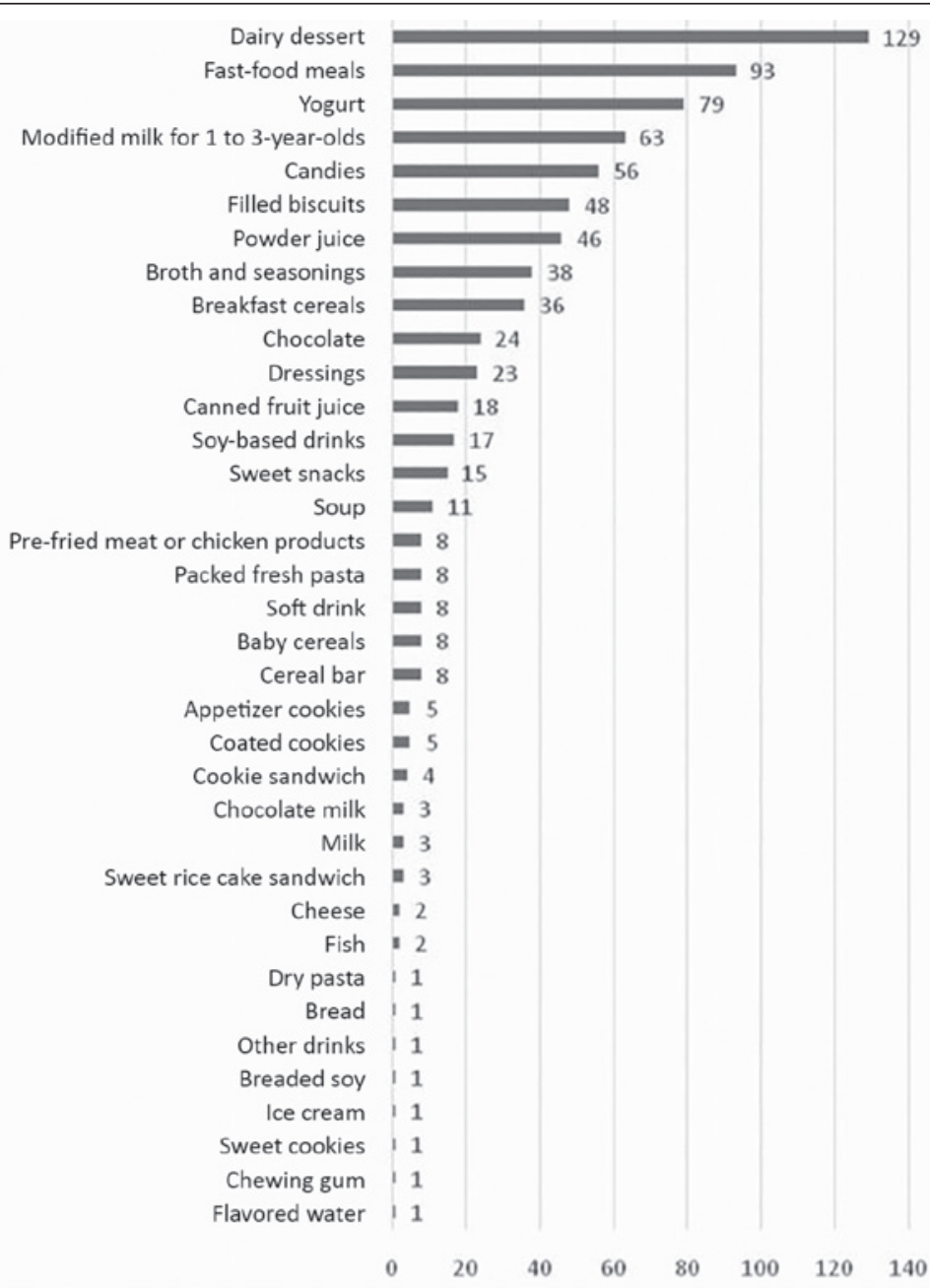


and beverage category and may, therefore, be broadcast with no restrictions during children's programming whereas almost two-thirds of advertised products $(64.2 \%)$ were considered unhealthy. Based on the categorization made according to the traffic light labeling model, it was observed that almost $50 \%$ of advertised food and beverages were high in sugar, $25 \%$ were high in saturated fat, $15 \%$ were high in sodium, and 16\% were high in total fat (Figure 2).

\section{DISCUSSION}

For more than four decades, advertising targeted at children has been the subject of research and debate. Marketing to children started in the 1970s for the purpose of understanding the nature and effects business communications had in the underage population. ${ }^{15}$ In relation to food and beverages, it has been demonstrated that advertising had an influence on children's food preferences, purchase requests, and consumption guidelines, and was associated with consumption of food that is high in calories, saturated fat, sodium, and sugar.,

This study evidences that, in Argentina, time destined to food and beverage commercials in children's programming is not that much; however, most advertised food products may be categorized as unhealthy. Food products ranked third ( $20 \%$ of all recorded commercials), and this is similar to what has been observed in Mexico, where between $18 \%{ }^{16}$ and $31 \%{ }^{17}$ of commercials corresponded to food and beverages, and is lower that what has been found in Chile (34\%). ${ }^{15}$

These findings are different from what had been observed two decades ago in 13 countries, when $70 \%$ of all television programming advertising targeted at children on weekends corresponded to food. ${ }^{18}$ Such reduction may possibly be the result of food and beverage advertising regulations.

In Argentina, food and beverage advertising in children's channels accounted, in average, for less than 1 minute per hour (0.7 minutes), and a maximum of 3.6 minutes per hour. The mean duration was lower than that observed in other studies using a similar methodology: in the United States, Gantz et al. found that it accounted for $>2 \mathrm{~min} /$ hour of the general programming, and $3 \mathrm{~min} /$ hour of children's programming only, ${ }^{19}$ and in Chile, Uribe Bravo observed that it accounted for $2 \mathrm{~min} /$ hour of children's programming. ${ }^{15}$

There is a great discrepancy in the nutritional quality of advertised food products and those recommended for the child population. ${ }^{6}$ In most countries, advertised food and beverages are high in calories, total fat, sugar, and sodium, and rarely include an adequate nutritional quality product. Taras and Gage ${ }^{20}$ evidenced that $69 \%$ of food advertised on television was high in sugar; $35 \%$, high in fat; and $20 \%$, high in sodium. In Mexico, a study conducted before the approval of the code of self-regulation of the advertising of food

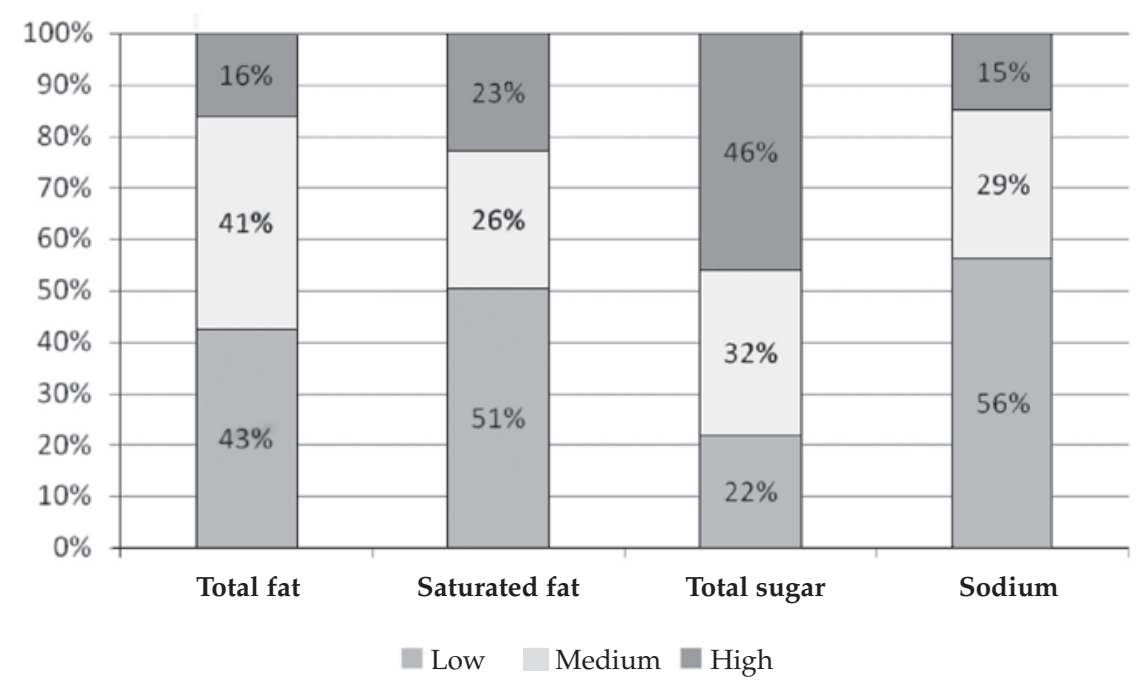


products directed at minors, prevention of obesity and health (PAOS code) observed that food advertised on television during children's shows was of small nutritional value and, generally, high in simple sugar and fat, and did not include fruits, vegetables or fish. ${ }^{17}$ Another study conducted in Mexico City found that food advertised in children's programming were high in calories, fat, and carbohydrates. ${ }^{16}$ In Chile, only $13 \%$ of commercials corresponded to healthy food and beverages; $8.5 \%$, to moderately healthy food and beverages; and $79 \%$, to unhealthy food products. ${ }^{21}$ These data are similar to those observed by Crovetto et al.: $9 \%$ corresponded to healthy food and beverages; $27 \%$, to moderately healthy food and beverages; and $64 \%$, to unhealthy food and beverages. ${ }^{22}$

The results obtained in this study show that $64 \%$ of food and beverage commercials were categorized as unhealthy based on the FSA's nutrient profiling model, and almost $50 \%$ of advertised food products were high in sugar, $25 \%$ were high in saturated fat, $15 \%$ were high in sodium, and $16 \%$ were high in total fat based on the traffic light labeling system.

In average, children watch 2 to 3 hours of television every day, ${ }^{23-25}$ and this accounts for approximately 5 food and beverage commercials; two-thirds of these advertise unhealthy products.

Based on the monitored programming, the most advertised products were dairy products (milk, yogurt, and desserts), followed by candies, fast-food meals, bread, and cookies; this is consistent with the findings made in Mexico, which demonstrated that, in both observation periods, the most commonly advertised food products were cookies, breakfast cereals, dairy products, ice cream, pastry, milkshakes, cocoa, and candies, ${ }^{17}$ and those made in Chile, which indicated that sugar-sweetened beverages, candies, and sugary cereals were the most advertised products. ${ }^{16}$

In Argentina, there are no regulations specifically related to food and beverage advertising targeted at children. The existing regulation (ANMAT provision no. 4980/2005) ${ }^{26}$ indicates that no phrases and/or messages exclusively or mainly targeted at children younger than 12 years old without adult supervision may be included. There are also no restrictions regarding nutritional criteria, as observed in other countries..$^{27}$ In compliance with the International Code of Marketing of Breast-milk Substitutes, ${ }^{28}$ no advertising has been made for infant formulas.
Law no. 26873 for the promotion and awareness of breastfeeding, regulated in January of $2015,{ }^{29}$ establishes the rules for the advertising of modified milk for children younger than 2 years old; therefore, commercials of modified milk for 1 to 3-year-olds, which ranked in the fourth place, should not be advertised at present in the jurisdictions that adhere to this law.

One of the main strengths of this study is that it is the first study of this nature conducted in Argentina. However, it is necessary to study other forms of food and beverage advertising outside television given that, at present, children are exposed to commercials on the Internet, social networks, school, and the streets.

The World Health Organization (WHO), in its document on the marketing of foods high in fat, salt, and sugar to children, ${ }^{9}$ calls for Member States to devise policies that reduce the exposure and power of marketing messages that promote the consumption of food high in saturated fat, trans-fatty acids, sugar and salt given that these are probably one of the multiple causes that contribute to the increase in obesity, and particularly points out that legislation is necessary to regulate food and beverage advertising because children may be incapable of discerning its commercial intent but are susceptible to its influence.

Promoting a healthy environment where children may develop eating habits and preferences that favor their present and future health is the responsibility of adults. The public health community, decision-makers, and the media have many opportunities to complete actions aimed at improving the environment where children develop.

\section{CONCLUSION}

Food and beverage advertising accounted for $20 \%$ of television advertising time. The most advertised products were dairy products, followed by candies and sweet snacks, fast-food meals, and beverages. Two-thirds of advertised food and beverages were considered unhealthy.

\section{Acknowledgments}

The authors would like to thank Mercedes Sobral, B.S., Gabriela Estévez, B.S., and Gabriel De Dominicis for their valuable contribution in data collection.

\section{REFERENCES}

1. Ministerio de Salud de la Nación. 2.a Encuesta Mundial deSalud Escolar. Argentina. 2012. Buenos Aires: MINSAL. 
2013. [Accessed on: September 22 $\left.{ }^{\text {nd }}, 2016\right]$. Available at: http://www.msal.gob.ar/ent/images/stories/vigilancia/ pdf/2014-09_informe-EMSE-2012.pdf.

2. World and Health Organization. Global Status Report on noncommunicable diseases. 2014. Attaining the nine global noncommunicable diseases targets; a shared responsibility. Geneva: WHO, 2014. [Accessed on: September $\left.22^{\text {nd }}, 2016\right]$. Available at: http: / / apps.who.int/ iris/bitstream/10665/148114/1/9789241564854_eng.pdf.

3. Lobstein T, Baur L, Uauy R. Obesity in children and young people: a crisis in public health. Obes Rev 2004;5(Suppl 1): 4-104.

4. Organización Mundial de la Salud. Conjunto de recomendaciones sobre la promoción de alimentos y bebidas no alcohólicas dirigida a los niños. Ginebra: OMS, 2010. [Accessed on: September 22 ${ }^{\text {nd }}$, 2016]. Available at: http://apps.who.int/iris/ bitstream/10665/44422/1/9789243500218_spa.pdf.

5. CairnsG, AngusK, Hastings G. The extent, nature and effects of food promotion to children: a review of the evidence to December 2008 Ginebra: Organización Mundial de la Salud;2009. [Accessed on:September $\left.22^{\text {nd }}, 2016\right]$. Available at: http://www.who.int/dietphysicalactivity/Evidence_ Update_2009.pdf.

6. Hastings G, Stead M, McDermatt L, Forsyth A, etal. Review of the research on the effects of food promotion to children. Final report. Glasgow: University of Strathclyde. Centre for Social Marketing; 2003. [Accessed on: September 22 ${ }^{\text {nd }}$, 2016]. Available at: http://www.sfu.ca/cmns/faculty/ marontate_j/801/08-spring/ClassFolders/Iwase_Masa/ SelectedTopicMaterials/foodpromotiontochildren1.pdf.

7. Hastings G, McDermott L, Angus K, Stead M, et al. The extent, nature and effects of food promotion to children: a review of the evidence. Technical paper prepared for tha World Helath Organization. Ginebra: Organización Mundial de la Salud; 2006. [Accessed on: September 22 $\left.{ }^{\text {nd }}, 2016\right]$. Available at: http://www.who. int/dietphysicalactivity/ publications/Hastings_paper_ marketing.pdf.

8. McGinnis JM, Gootman JA, Kraak VI. Food marketing to children and youth: threat or opportunity? Washington DC: National Academy Press, 2006.

9. World Health Organization. Marketing of foods high in fat, salt and sugar to children: update 2012-2013. Copenhagen: WHO, 2013. [Accessed on: September $22^{\text {nd }}$, 2016]. Available at: http://www.euro.who.int/ data/ assets/pdf_file/0019/191125/e96859.pdf.

10. Organización Panamericana de la Salud. Recomendaciones dela Consulta deExpertos dela Organización Panamericana de la Salud sobre la promoción y publicidad de alimentos y bebidas no alcohólicas dirigida a los niños en la Región de las Américas. Washington, DC: OPS, 2011. [Accessed on:September 22 ${ }^{\text {nd }}$, 2016]. Available at: http:/ / www.paho. $\mathrm{org} / \mathrm{hq} /$ index.php?option $=$ com_docman\&task $=$ doc view\&gid $=18285 \&$ Itemid $=270$.

11. World Health Organization. Report of the commission on ending childhood obesity. Geneva: WHO, 2016. [Accessed on: September 22 $\left.{ }^{\text {nd }}, 2016\right]$. Available at: http:/ / apps.who. int/iris/bitstream/10665/204176/1/9789241510066_eng. pdf.

12. Observatorio de Industrias Creativas. El sector de la Televisión en Argentina y Ciudad de Buenos Aires. Informe 2014. [Accessed on: September $22^{\text {nd }}, 2016$ ]. Available at: http:/ / www.buenosaires.gob.ar/sites/gcaba/files / informes_oic_2014_-_tv_-_final.pdf.

13. Department of Health. Nutrient Profiling Technical Guidance 2011. [Accessed on: September 22 $\left.2^{\text {nd }}, 2016\right]$. Available at: https://www.gov.uk/government/ uploads/system/ uploads/attachment_data/file/216094/ dh_123492.pdf.

14. Food Standards Agency. Front of pack traffic light signspot labeling TechnicalGuidance. 2007. [Accessed on:September $\left.22^{\text {nd }}, 2016\right]$. Available at: http://www.ampelcheck.de/ files/000000/658_grundlagen_der_ampelkennzeichnung. pdf.

15. Uribe Bravo R. Un momento y ya volvemos: un análisis de contenido de la publicidad infantil en la televisión chilena. Com Soc (Guadalaj) 2012;18:79-106.

16. Pérez-Salgado D, Rivera-Márquez JA, Ortiz-Hernández L. Publicidad de alimentos en la programación de la televisión mexicana: ¿los niños están más expuestos? Salud Pública Méx 2010;52(2):119-26.

17. Menéndez García RA, Franco Díez FJ. Publicidad y alimentación: influencia de los anuncios gráficos en las pautas alimentarias de infancia y adolescencia. Nutr Hosp 2009;24(3):318-25.

18. Dibb S. A spoonful of sugar Television food advertising aimed at children; an international comparative survey. London: Consumers International, 1996. [Accessed on: September 22 $\left.2^{\text {nd }}, 2016\right]$. Available at: http://www. consumersinternational.org/media/308610/a\%20 spoonful $\% 20$ of $\% 20$ sugar $\% 20-\% 20$ television $\% 20$ food $\% 20$ advertising $\% 20$ aimed $\% 20$ at $\% 20$ children-\%20an $\% 20$ international\%20comparative \%20survey.pdf.

19. Gantz W, Schwartz N, Angelini JR, Rideout V. Food for Thought Television Food Advertising to Children in the United States. A Kaiser Family Foundation Report 7618. Kaiser Family Foundation; 2007. [Accessed on: September $\left.22^{\text {nd }}, 2016\right]$. Available at: https:/ / kaiserfamilyfoundation. files.wordpress.com/2013/01/7618.pdf.

20. Taras HL, Gages M. Advertised foods on children's television. Arch Pediatr Adolesc Med 1995;149(6):649-52.

21. Castillo-Lancellotti C, Pérez-Santiago O, Rivas-Castillo C, Fuentes-García R, et al. Análisis de la publicidad de alimentos orientada a niños y adolescentes en canales chilenos de televisión abierta. Rev Esp Nutr Comunitaria 2010;16(2):90-7.

22. Crovetto MM, Durán TM, Guzmán RM, Miranda HC. Estudio descriptivo de la frecuencia y duración de la publicidad alimentaria emitida en la programación de canales de televisión asociados a Anatel. Rev Chil Nutr 2011;38(3):209-99.

23. Morduchowicz R, Marcon A, Minzi V, Camarda P. ¿Cómo orientar a los más chicos cuando ven televisión? La tele en familia. Buenos Aires: Ministerio de Educación, Ciencia y Tecnología, 2005. [Accessed on: September 22 ${ }^{\text {nd }}, 2016$ ]. Available at: http://servicios.abc.gov.ar/ alumnos/ escuelasmedios/materialconsulta/tele_familia1.pdf.

24. Kovalskys I, Holway F, Ugalde V, De Gregorio M. Análisis sobre los factores vinculados a sobrepeso y obesidad en niños de 10 y 11 años que asisten a escuelas públicas en el área metropolitana de Buenos Aires. Buenos Aires: ILSI, 2007.

25. American Academy of Pediatrics, Committee on Public Education. American Academy of Pediatrics: Children, Adolescents, and Television. Pediatrics 2001;107(2):423-6.

26. Ministerio de Salud de la Nación. Disposición ANMAT N. ${ }^{\circ}$ 4980/2005 (con las modificaciones de la Disp. ANMAT N. ${ }^{\circ}$ 7730/2011). Buenos Aires, septiembre 2005. [Accessed on: September 22 $\left.{ }^{\text {nd }}, 2016\right]$. Available at: http://www.anmat. gov.ar/webanmat/ Legislacion/NormasGenerales / Disposicion_ANMAT_4980-2005.pdf.

27. Letona P. Estudio exploratorio sobre la promoción y publicidad de alimentos y bebidas no saludables dirigida a niños en América Latina y el Caribe. Panamá: UNICEF, 2013. [Accessed on: September 22 $\left.{ }^{\text {nd }}, 2016\right]$. Available at: http:/ / 
www.unicef.org/lac/Estudio_exploratorio_promocion_ alimentos_no_saludables_a_ninos_en_LAC_-_Informe_ Completo_(2).pdf.

28. World and Health Organization. International Code of Marketing of Breast-milk Substitutes. Geneva.1981.
[Accessed on: September 22 $\left.{ }^{\text {nd }}, 2016\right]$. Available at: http:// www.who.int/nutrition/publications/code_english.pdf. 29. Ley N. ${ }^{\circ}$ 26873.Decreto22/2015.PromociónyConcientización Pública de la Lactancia Materna. Boletín Oficial de la República Argentina, Buenos Aires, Argentina, 14 de enero de 2015. 